\title{
Synthesis and characterization of titanium(IV) complexes containing the diphenylphosphino- and diphenylthiophosphoryl-functionalized cyclopentadienyl ligand. Crystal and molecular structure of $\mathrm{Ti}\left(\eta^{5}-\mathrm{C}_{5} \mathrm{H}_{4} \mathrm{PPh}_{2}\right) \mathrm{Cl}_{3}$
}

\author{
Juan C. Flores a, Rocío Hernández a, Pascual Royo ${ }^{\mathrm{a}, 1}$, Angelika Butt ${ }^{\mathrm{b}}$, \\ Thomas P. Spaniol ${ }^{\mathrm{b}}$, Jun Okuda ${ }^{\mathrm{b}, *}$ \\ a Departmento de Química Inorgánica, Universidad de Alcalá, Campus Universitario, E-28871 Alcalá de Henares, Spain \\ ${ }^{\mathrm{b}}$ Institut für Anorganische Chemie und Analytische Chemie, Johannes Gutenberg-Universität Mainz, Duesbergweg 10-14, \\ D-55099 Mainz, Germany
}

Received 4 June 1999; accepted 13 July 1999

Dedicated to Professor Fausto Calderazzo on the occasion of his 70th birthday.

\begin{abstract}
The trimethylsilyl cyclopentadiene derivative $\mathrm{C}_{5} \mathrm{H}_{4}\left(\mathrm{SiMe}_{3}\right) \mathrm{PPh}_{2}(\mathbf{1})$ was treated with $\mathrm{TiCl}_{4}$ to give the air- and moisture-sensitive mono(cyclopentadienyl) compound $\mathrm{Ti}\left(\eta^{5}-\mathrm{C}_{5} \mathrm{H}_{4} \mathrm{PPh}_{2}\right) \mathrm{Cl}_{3}$ (4). Reaction of 4 with $\mathrm{Mg}\left(\mathrm{CH}_{2} \mathrm{C}_{6} \mathrm{H}_{5}\right)_{2}(\mathrm{THF})_{2}$ gave $\mathrm{Ti}\left(\eta^{5}\right.$ $\left.\mathrm{C}_{5} \mathrm{H}_{4} \mathrm{PPh}_{2}\right)\left(\mathrm{CH}_{2} \mathrm{C}_{6} \mathrm{H}_{5}\right)_{3}(5)$. Reactions of the lithium and thallium derivatives $\mathrm{M}\left\{\mathrm{C}_{5} \mathrm{H}_{4} \mathrm{P}\left(\mathrm{S}_{)}\right) \mathrm{Ph}_{2}\right\} \quad(\mathrm{M}=\mathrm{Li}$ (2), Tl (3)) with one equiv. of $\mathrm{TiCl}_{4}$ afforded the mono(cyclopentadienyl) complex $\mathrm{Ti}\left\{\eta^{5}-\mathrm{C}_{5} \mathrm{H}_{4} \mathrm{P}(\mathrm{S}) \mathrm{Ph}_{2}\right\} \mathrm{Cl}_{3}(\mathbf{6})$, whereas reaction with 0.5 equiv. of $\mathrm{TiCl}_{4}$ gave the bis(cyclopentadienyl) complex Ti $\left\{\eta^{5}-\mathrm{C}_{5} \mathrm{H}_{4} \mathrm{P}(\mathrm{S}) \mathrm{Ph}_{2}\right\}_{2} \mathrm{Cl}_{2}(\mathbf{8})$. Compound 6 was also isolated as a minor product from the reaction of $\mathrm{Ti}\left\{\eta^{5}-\mathrm{C}_{5} \mathrm{H}_{4} \mathrm{P}(\mathrm{S}) \mathrm{Ph}_{2}\right\}_{2} \mathrm{Cl}_{2}(8)$ with one equiv. of $\mathrm{TiCl}_{4}$. The major product was identified as an inseparable mixture of two compounds $\left[\mathrm{Ti}\left\{\eta^{5}-\mathrm{C}_{5} \mathrm{H}_{4} \mathrm{P}(\mathrm{S}) \mathrm{Ph}_{2}\right\}_{2} \mathrm{Cl}_{2} \cdot \mathrm{TiCl}_{4}\right]_{n}$ (7a and 7b). Reaction of $\mathrm{Ti}\left(\eta^{5}-\mathrm{C}_{5} \mathrm{H}_{5}\right) \mathrm{Cl}_{3}$ with 3 afforded the 'mixed-ring' bis(cyclopentadienyl) complex Ti $\left\{\eta^{5}-\mathrm{C}_{5} \mathrm{H}_{4} \mathrm{P}(\mathrm{S}) \mathrm{Ph}_{2}\right\}\left(\eta^{5}-\mathrm{C}_{5} \mathrm{H}_{5}\right) \mathrm{Cl}_{2}(\mathbf{9})$. Compounds 6-9 are very moisture-sensitive and easily decompose to form the cyclopentadiene $\mathrm{C}_{5} \mathrm{H}_{5} \mathrm{P}(\mathrm{S}) \mathrm{Ph}_{2}$. Structural data of these complexes indicate $\eta^{5}$-coordination of the substituted cyclopentadienyl ligands and this coordination mode was confirmed by X-ray crystal structure analysis of compound 4. (C) 2000 Elsevier Science S.A. All rights reserved.
\end{abstract}

Keywords: Cyclopentadienyl ligand; Phosphorus; Titanium; Ligand redistribution

\section{Introduction}

Of the functionalized cyclopentadienyl ligands for transition metal centers [1], those with an intramolecularly coordinated additional donor group [2] have attracted considerable interest recently. Group 4 metal complexes containing one such bidentate ligand are particularly important homogeneous polymerization catalyst precursors [3]. On the other hand, the substituent effects of heteroatom functions directly bonded to the periphery of the cyclopentadienyl ring have not

* Corresponding author.

${ }^{1}$ Also corresponding author. been developed extensively, although the corresponding cyclopentadienes are easily accessible [4]. Such ligands systems are known to form polynuclear complexes by intermolecular coordination to other metal fragments [5]. Therefore we set out to explore the chemistry of titanium(IV) complexes containing the diphenylphosphino- and diphenylthiophosphoryl-cyclopentadienyl ligands. We describe here the synthesis of the new mono(cyclopentadienyl) compounds $\mathrm{Ti}\left(\eta^{5}-\mathrm{C}_{5} \mathrm{H}_{4} \mathrm{PPh}_{2}\right)$ $\mathrm{Cl}_{3}$ and $\mathrm{Ti}\left\{\eta^{5}-\mathrm{C}_{5} \mathrm{H}_{4} \mathrm{P}(\mathrm{S}) \mathrm{Ph}_{2}\right\} \mathrm{Cl}_{3}$ and the bis(cyclopentadienyl) complexes $\mathrm{Ti}\left\{\eta^{5}-\mathrm{C}_{5} \mathrm{H}_{4} \mathrm{P}(\mathrm{S}) \mathrm{Ph}_{2}\right]_{2} \mathrm{Cl}_{2}$ and $\mathrm{Ti}\left\{\eta^{5}-\mathrm{C}_{5} \mathrm{H}_{4} \mathrm{P}(\mathrm{S}) \mathrm{Ph}_{2}\right]\left(\eta^{5}-\mathrm{C}_{5} \mathrm{H}_{5}\right) \mathrm{Cl}_{2}$. During the course of this study, the synthesis of several similar complexes was reported independently [6]. 


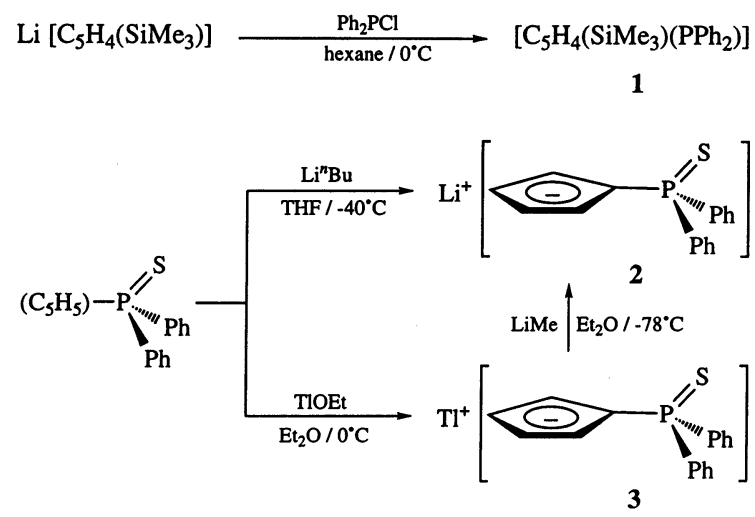

Scheme 1.

\section{Results and discussion}

Addition of one equiv. of $\mathrm{Ph}_{2} \mathrm{PCl}$ to $\mathrm{Li}\left(\mathrm{C}_{5} \mathrm{H}_{4} \mathrm{SiMe}_{3}\right)$ gives the cyclopentadiene $\mathrm{C}_{5} \mathrm{H}_{4}\left(\mathrm{SiMe}_{3}\right) \mathrm{PPh}_{2}$ (1) which can be isolated as an orange-yellow oil in high yield (Scheme 1). The product is soluble in hexane and $\mathrm{CH}_{2} \mathrm{Cl}_{2}$, and according to its ${ }^{1} \mathrm{H}-\mathrm{NMR}$ spectrum it is sufficiently pure to be used in subsequent complexation reactions. The ${ }^{1} \mathrm{H}-\mathrm{NMR}$ spectrum contains one broad singlet and two multiplets for the cyclopentadienyl protons indicating the presence of a mixture of isomers. Addition of one equiv. of $\mathrm{Li}^{n} \mathrm{Bu}$ to $\mathrm{C}_{5} \mathrm{H}_{5} \mathrm{P}(\mathrm{S}) \mathrm{Ph}_{2}$ affords compound $\mathrm{Li}\left\{\mathrm{C}_{5} \mathrm{H}_{4} \mathrm{P}(\mathrm{S}) \mathrm{Ph}_{2}\right\}$ (2) in quantitative yield (Scheme 1). A THF adduct (ratio $\mathrm{THF} / \mathrm{Li}=2$ ) of this lithium salt was isolated as a highly air-sensitive foamy yellowish-white solid, soluble in aromatic solvents and THF. This compound was also obtained from the metal exchange reaction of the thallium derivative $\mathrm{Tl}\left\{\mathrm{C}_{5} \mathrm{H}_{4} \mathrm{P}(\mathrm{S}) \mathrm{Ph}_{2}\right\}$ (3) with LiMe (Scheme 1), where the initial formation of the byproduct 'TlMe' can be inferred, since its disproportionation products were detected $\left(\mathrm{Tl}^{0}\right.$ and $\left.\mathrm{TlMe}_{3}\right)$ [7]. The ${ }^{1} \mathrm{H}-\mathrm{NMR}$ spectrum of 2 shows a relatively broad virtual doublet $(\delta 6.45)$ for the AA'BB'X spin system corresponding to the fragment, with $J(\mathrm{P}, \mathrm{H})=4.5 \mathrm{~Hz}$ for the four protons. This pattern together with a singlet observed in the ${ }^{31} \mathrm{P}\left\{{ }^{1} \mathrm{H}\right\}$ NMR spectrum ( $\delta 41.18)$, indicates that the cyclopentadienyl group of the starting thiophosphoryl compound has been deprotonated.

Reaction of $\mathrm{C}_{5} \mathrm{H}_{5} \mathrm{P}(\mathrm{S}) \mathrm{Ph}_{2}$ with one equiv. of TlOEt in diethyl ether affords $\mathbf{3}$ as an air-sensitive brown powder (Scheme 1). Unlike $\mathrm{Tl}\left(\mathrm{C}_{5} \mathrm{H}_{5}\right)$, compound 3 is soluble enough in aromatic solvents to allow its study by NMR spectroscopy. The NMR data for $\mathbf{3}$ are also consistent with deprotonation of the cyclopentadienyl ring. The ${ }^{1} \mathrm{H}$ NMR spectrum in $\mathrm{C}_{6} \mathrm{D}_{6}$ shows the $\mathrm{C}_{5} \mathrm{H}_{4} \mathrm{P}$ group as an $\mathrm{AA}^{\prime} \mathrm{BB}^{\prime} \mathrm{X}$ spin system (two doublets of virtual triplets at $\delta 6.17$ and 6.48$)$ with $J(\mathrm{P}, \mathrm{H})=4.0 \mathrm{~Hz}$ for the protons of the ring. The ${ }^{13} \mathrm{C}\left\{{ }^{1} \mathrm{H}\right\}$-NMR chemical shifts and ${ }^{31} \mathrm{P}-{ }^{13} \mathrm{C}$ coupling values of $\mathbf{3}$ are also within normal ranges for cyclopentadienyl carbons (see Section 4);

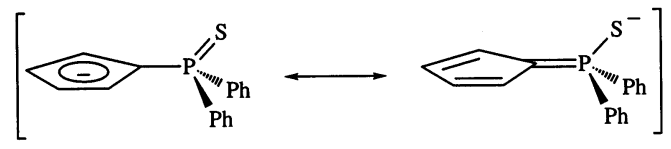

I

II

Fig. 1. Resonance structures for the $\left[\mathrm{C}_{5} \mathrm{H}_{4} \mathrm{P}\left(\mathrm{S}_{)} \mathrm{Ph}_{2}\right]^{-}\right.$.

one singlet appears in its ${ }^{31} \mathrm{P}\left\{{ }^{1} \mathrm{H}\right\}$ NMR spectrum $(\delta$ 38.75). The presence of ${ }^{1} \mathrm{H}-$ and ${ }^{13} \mathrm{C}-{ }^{203,205} \mathrm{Tl}$ coupling constants for soluble substituted (cyclopentadienyl)thallium compounds has been attributed to the enforced covalency of the metal-ring interaction in the compound [8]. The absence of ${ }^{1} \mathrm{H},{ }^{13} \mathrm{C}$ and ${ }^{31} \mathrm{P}$ couplings with ${ }^{203,205} \mathrm{Tl}$ in the spectra of compound $\mathbf{3}$ may indicate that the interaction in $\mathbf{3}$ is predominantly ionic in character. The two resonance structures for the anion $\left[\mathrm{C}_{5} \mathrm{H}_{4} \mathrm{P}(\mathrm{S}) \mathrm{Ph}_{2}\right]^{-}$, shown in Fig. 1, might help to delocalize negative charge to the ligand, thus encouraging ionic bonding in the thallium complex.

Several approaches have proved useful for the synthesis of group 4 mono- and bis(cyclopentadienyl) chloro complexes. For example, the reaction of $\mathrm{TiCl}_{4}$ with trimethylsilylcyclopentadienes is an efficient method for the synthesis of mono(cyclopentadienyl) complexes [9]. Further reaction of the mono(cyclopentadienyl) complex with a thallium derivative of a different cyclopentadienyl ligand affords 'mixed-ring' titanium compounds [10]. However, the reaction of $\mathrm{TiCl}_{4}$ with two equiv. of an alkali metal cyclopentadienyl salt is the most commonly used procedure for the synthesis of dichlorobis(cyclopentadienyl)titanium complexes [11]. Thus, compounds $4,6,8$, and 9 were readily prepared from precursors 1-3 (Scheme 2).

The titanium trichloro complex $\mathbf{4}$ was formed as a purple solid, in good yield, by addition of 1 to $\mathrm{TiCl}_{4}$ in $\mathrm{CH}_{2} \mathrm{Cl}_{2}$. Recrystallization attempts from a variety of solvents proved difficult because the complex decomposed in most instances to insoluble yellow-white powders that could not be characterized. Eventually we succeeded in obtaining $\mathbf{4}$ as shiny purple crystals suitable for single-crystal $\mathrm{X}$-ray analysis using a $\mathrm{CH}_{2} \mathrm{Cl}_{2}$ / hexane mixture. The ${ }^{1} \mathrm{H}-\mathrm{NMR}$ spectrum of $\mathbf{4}$ contains two multiplets for the protons on the substituted cyclopentadienyl ring, together with characteristic resonances for the phenyl groups. A singlet is observed at $-6.64 \mathrm{ppm}$ in the ${ }^{31} \mathrm{P}-\mathrm{NMR}$ spectrum. Reaction of 4 with $\left(\mathrm{C}_{6} \mathrm{H}_{5} \mathrm{CH}_{2}\right)_{2} \mathrm{Mg}(\mathrm{THF})_{2}$ in toluene yielded the tribenzyltitanium complex $\mathbf{5}$ as brown microcrystals. The ${ }^{1} \mathrm{H}-\mathrm{NMR}$ spectrum contained one singlet at 3.00 ppm for the $\mathrm{TiCH}_{2}$ protons with the signals for the cyclopentadienyl protons shifted significantly upfield.

The crystal structure of $\mathbf{4}$ was determined by X-ray diffraction on a single crystal. Fig. 2 shows an ORTEP plot of the molecular structure and Table 1 summarizes selected bond distances and angles. The geometry 
around the metal atom can be described as a pianostool configuration similar to $\operatorname{Ti}\left(\eta^{5}-\mathrm{C}_{5} \mathrm{H}_{5}\right) \mathrm{Cl}_{3}$ [12a]. The $\eta^{5}$-bonded cyclopentadienyl ring is practically planar with $\mathrm{Ti}-\mathrm{C}$ bond distances ranging between 2.330(2) and 2.365(2) $\AA$ and with $\mathrm{C}-\mathrm{C}$ bond distances between 1.401(3) and 1.423(2) $\AA$. Only the distance to the carbon atom $\mathrm{C}(13)$ bearing the phosphorus appears slightly elongated, but the cyclopentadienyl fragment can be regarded as $\eta^{5}$-coordinated. The distance between the ring centroid and the Ti center is $2.01 \AA$, similar to the value for $\operatorname{Ti}\left(\eta^{5}-\mathrm{C}_{5} \mathrm{H}_{5}\right) \mathrm{Cl}_{3}$. The phosphorus atom deviates from the plane formed by the five ring atoms by $0.25 \AA$ and is directed towards the metal atom. The Ti-P distance of 3.525(1) $\AA$, however, excludes a bonding interaction. The phenyl rings attached to the phosphorus atom form angles of 80 and $60^{\circ}$ with respect to the plane defined by the cyclopentadienyl ring. The $\mathrm{Ti}-\mathrm{Cl}$ bond distances as well as the $\mathrm{Cl}-\mathrm{Ti}-\mathrm{Cl}$ angles closely correspond to those of $\mathrm{Ti}\left(\eta^{5}-\right.$ $\left.\mathrm{C}_{5} \mathrm{H}_{5}\right) \mathrm{Cl}_{3}$ and other related monosubstituted-cyclopentadienyl complexes [12].

Slow addition of either $\mathbf{2}$ or $\mathbf{3}$ in toluene, to a toluene solution of $\mathrm{TiCl}_{4}$ gives the mono(cyclopentadienyl) complex 6 as a yellow-orange oil, soluble in $\mathrm{CH}_{2} \mathrm{Cl}_{2}$ and toluene (Scheme 2). The moderate solubility of the thallium compound 3 in toluene makes the reaction sensitive to the rate of addition. Fast addition leads to a mixture of $\mathbf{6}$ and the bis(cyclopentadienyl) compound 8. Conversely, only compound $\mathbf{6}$ was isolated (65\% yield after workup) when the suspension was added in small portions. The higher solubility of the lithium salt allows better control of the addition process, resulting in a higher yield of 6 (ca. 90\%). However, because $\mathbf{2}$ was isolated as a THF adduct, the titanium compound was contaminated with small amounts of $\mathrm{TiCl}_{4}(\mathrm{THF})_{2}$. Ligand redistribution was also used to synthesize $\mathbf{6}$ [12], by treatment of $\mathbf{8}$ with 1 equiv. of $\mathrm{TiCl}_{4}$ in warm toluene (Scheme 2). Compound 6 was isolated as the minor product $(<20 \%)$ from this reaction, with a mixture of two compounds $7 \mathbf{a}$ and $\mathbf{7 b}$ as the major products (vide infra).

Compound 6, regardless of the procedure used to prepare it, was invariably isolated as an oil with at least 1 equiv. of toluene present, and is more moisturesensitive than $\operatorname{Ti}\left(\eta^{5}-\mathrm{C}_{5} \mathrm{H}_{5}\right) \mathrm{Cl}_{3}$. Attempts to crystallize this compound (washing with alkanes, recrystallization from toluene or from mixtures of solvents), or to remove toluene (high vacuum: $10^{-6} \mathrm{mbar}$, at room temperature or $50^{\circ} \mathrm{C}$ ), all failed. In fact, repeated crystallization gave successive fractions of a yellow solid, and samples of $\mathbf{6}$ under high vacuum were also converted quantitatively to the same yellow solid. This solid has been characterized as a mixture of compounds 7 (vide infra). The ${ }^{1} \mathrm{H}-\mathrm{NMR}$ spectrum of $\mathbf{6}$ shows a complicated $\mathrm{AA}^{\prime} \mathrm{BB}^{\prime} \mathrm{X}$ spin system for the substituted cyclopentadienyl ring, recorded as two quartets $(\delta 6.02$ and 6.79), together with characteristic resonances for the phenyl groups and toluene protons, and its ${ }^{31} \mathrm{P}\left\{{ }^{1} \mathrm{H}\right\}$-NMR spectrum contains one singlet at $\delta 38.8$.
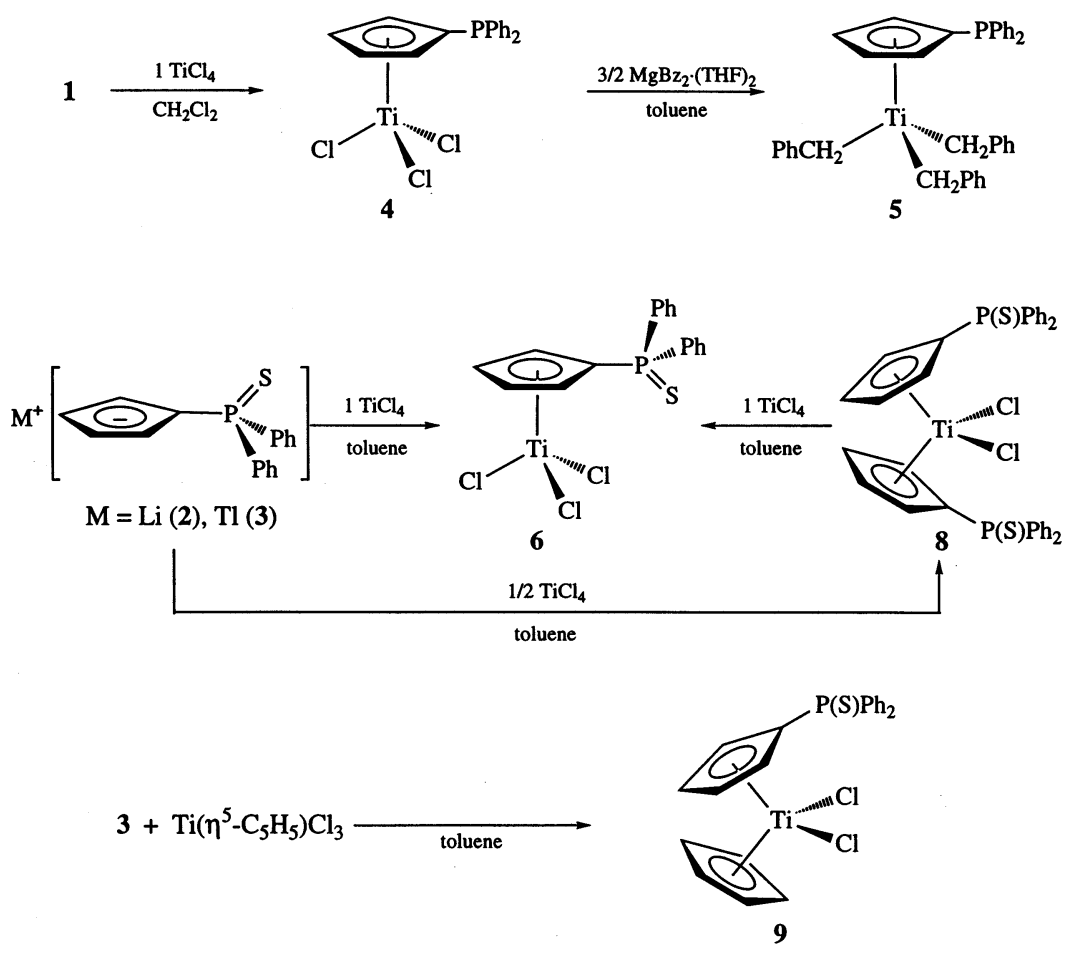

Scheme 2. 

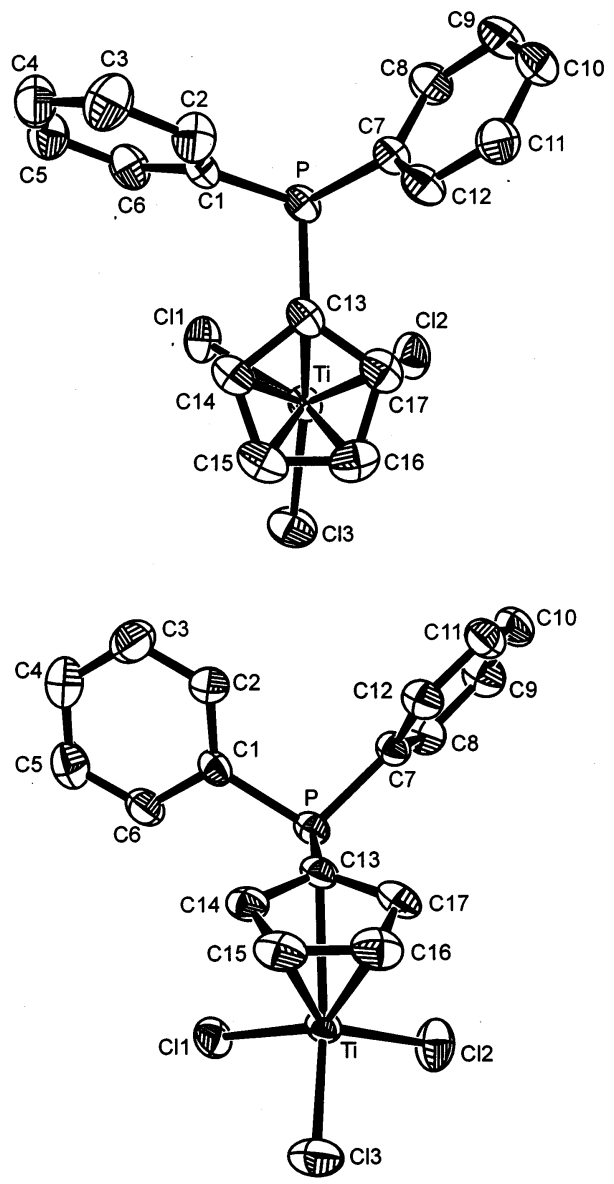

Fig. 2. ORTEP diagram of the molecular structure of $\mathrm{Ti}\left(\eta^{5}\right.$ $\left.\mathrm{C}_{5} \mathrm{H}_{4} \mathrm{PPh}_{2}\right) \mathrm{Cl}_{3}$ (4). Thermal ellipsoids are drawn at 50\% probability level. Hydrogen atoms are omitted for the sake of clarity.

Reaction of $\mathbf{3}$ (or 2) with $\mathrm{TiCl}_{4}$ in a 2:1 molar ratio in toluene affords the bis(cyclopentadienyl) compound $\mathbf{8}$ (Scheme 2), while treatment of $\operatorname{Ti}\left(\eta^{5}-\mathrm{C}_{5} \mathrm{H}_{5}\right) \mathrm{Cl}_{3}$ with 1 equiv. of $\mathbf{3}$ gives the "mixed-ring" bis(cyclopentadienyl)

Table 1

Selected bond lengths $(\AA)$ and angles $\left(^{\circ}\right)$ for $\operatorname{Ti}\left(\eta^{5}-\mathrm{C}_{5} \mathrm{H}_{4} \mathrm{PPh}_{2}\right) \mathrm{Cl}_{3}(\mathbf{4})$

\begin{tabular}{llll}
\hline Bond lenghts & \multicolumn{3}{l}{ Bond angles } \\
\hline $\mathrm{Ti}-\mathrm{Cl}(1)$ & $2.2427(8)$ & $\mathrm{Cl}(2)-\mathrm{Ti}-\mathrm{Cl}(3)$ & $102.65(3)$ \\
$\mathrm{Ti}-\mathrm{Cl}(2)$ & $2.2225(8)$ & $\mathrm{Cl}(2)-\mathrm{Ti}-\mathrm{Cl}(1)$ & $104.57(3)$ \\
$\mathrm{Ti}-\mathrm{Cl}(3)$ & $2.2318(9)$ & $\mathrm{Cl}(3)-\mathrm{Ti}-\mathrm{Cl}(1)$ & $101.72(3)$ \\
$\mathrm{Ti}-\mathrm{C}(13)$ & $2.365(2)$ & $\mathrm{C}(7)-\mathrm{P}-\mathrm{C}(13)$ & $102.55(7)$ \\
$\mathrm{Ti}-\mathrm{C}(14)$ & $2.339(2)$ & $\mathrm{C}(7)-\mathrm{P}-\mathrm{C}(1)$ & $103.76(8)$ \\
$\mathrm{Ti}-\mathrm{C}(15)$ & $2.330(2)$ & $\mathrm{C}(13)-\mathrm{P}-\mathrm{C}(1)$ & $100.48(7)$ \\
$\mathrm{Ti}-\mathrm{C}(16)$ & $2.335(2)$ & & \\
$\mathrm{Ti}-\mathrm{C}(17)$ & $2.347(2)$ & & \\
$\mathrm{P}-\mathrm{C}(1)$ & $1.839(2)$ & & \\
$\mathrm{P}-\mathrm{C}(7)$ & $1.822(2)$ & & \\
$\mathrm{P}-\mathrm{C}(13)$ & $1.830(2)$ & & \\
$\mathrm{C}(13)-\mathrm{C}(14)$ & $1.418(2)$ & & \\
$\mathrm{C}(13)-\mathrm{C}(17)$ & $1.423(2)$ & & \\
$\mathrm{C}(14)-\mathrm{C}(15)$ & $1.404(2)$ & \\
$\mathrm{C}(15)-\mathrm{C}(16)$ & $1.401(3)$ & \\
$\mathrm{C}(16)-\mathrm{C}(17)$ & $1.407(3)$ & \\
\hline
\end{tabular}

9; both 8 and $\mathbf{9}$ were obtained as red microcrystalline solids. Again, the purification of $\mathbf{8}$ proceeds more smoothly when $\mathbf{3}$ is used as cyclopentadienyl transfer reagent, since $\mathrm{TiCl}_{4}(\mathrm{THF})_{2}$ is also formed in the reaction of 2 with $\mathrm{TiCl}_{4}$, and this has been found to be difficult to separate. Solid samples of compound $\mathbf{8}$ contain toluene which persists after exposure to high vacuum. However, in this case, recrystallization from $\mathrm{CH}_{2} \mathrm{Cl}_{2}$ gives $\mathbf{8}$ free of solvent. Compounds $\mathbf{8}$ and $\mathbf{9}$ are very moisture-sensitive in contrast to the general stability of bis(cyclopentadienyl)-dichlorotitanium complexes (e.g. $\left.\mathrm{Ti}\left(\mathrm{C}_{5} \mathrm{H}_{5}\right)_{2} \mathrm{Cl}_{2}\right)$. The NMR spectra of $\mathbf{8}$ and $\mathbf{9}$, with additional signals due to the nonsubstituted five-membered ring in the latter, are fairly similar to that recorded for $\mathbf{6}$, and are in agreement with the structures proposed in Scheme 2. The $\mathrm{C}_{5} \mathrm{H}_{4} \mathrm{P}$ moiety is an $\mathrm{AA}^{\prime} \mathrm{BB}^{\prime} \mathrm{X}$ spin system, observed as two quartets at low field in the ${ }^{1} \mathrm{H}$-, as three doublets in the ${ }^{13} \mathrm{C}\left\{{ }^{1} \mathrm{H}\right\}$-, and as one singlet in the ${ }^{31} \mathrm{P}\left\{{ }^{1} \mathrm{H}\right\}-\mathrm{NMR}$ spectra.

It is well documented that trichloro(cyclopentadienyl)titanium complexes are oxophilic species whose $\mathrm{Ti}-\mathrm{Cl}$ bonds are easily hydrolyzed to give various $\mathrm{Ti}-\mathrm{O}-\mathrm{Ti}$ products depending on the reaction conditions [13]. In contrast, dichlorobis(cyclopentadienyl) titanium complexes are less oxophilic and more resistant to hydrolysis because they are less electron-deficient and are more coordinatively saturated. Indeed, much more severe conditions are usually needed to hydrolyze their $\mathrm{Ti}-\mathrm{Cl}$ bonds in reactions where the cyclopentadienyl ligands also remain unaffected [14]. This general behavior contrasts with the extreme moisture-sensitivity of the compounds containing the $\mathrm{C}_{5} \mathrm{H}_{4} \mathrm{P}(\mathrm{S}) \mathrm{Ph}_{2}$ ligand (i.e. 6-9), since brief exposure to air results in their rapid hydrolysis to re-form the starting compound $\mathrm{C}_{5} \mathrm{H}_{5} \mathrm{P}(\mathrm{S}) \mathrm{Ph}_{2}$.

This unusual behavior has been studied in detail by NMR-tube scale experiments for compound 8 . The ${ }^{1} \mathrm{H}-\mathrm{NMR}$ spectrum of samples of $\mathbf{8}$ in $\mathrm{C}_{6} \mathrm{D}_{6}$, recorded soon after the addition of $\mathrm{H}_{2} \mathrm{O}\left(\right.$ or $\left.\mathrm{D}_{2} \mathrm{O}\right)$ in a 2:1 molar ratio, shows half of the initial $\mathbf{8}$ unreacted and the resonances corresponding to $\mathrm{C}_{5} \mathrm{H}_{5} \mathrm{P}(\mathrm{S}) \mathrm{Ph}_{2}$ (or $\left.\mathrm{C}_{5} \mathrm{H}_{4} \mathrm{DP}(\mathrm{S}) \mathrm{Ph}_{2}\right)$ in a 8 /cyclopentadiene ratio of $1: 2$ [15]. The titanium-cyclopentadienyl bond apparently has a poor stability towards hydrolysis than that of the $\mathrm{Ti}-\mathrm{Cl}$ bonds in $\mathbf{8}$, as evidenced by the $\mathbf{8}$ /cyclopentadiene ratio observed in the spectrum which increases when excess (1:10) of $\mathrm{H}_{2} \mathrm{O}$ (or $\mathrm{D}_{2} \mathrm{O}$ ) is added.

Splitting cyclopentadienyl-transition metal bonds by reaction with protic substances is a reaction typically used in compounds of very electropositive metals (e.g. lanthanide systems) with notable ionic bond character [12c]. The mentioned yellow solid 7 consisting of a mixture of two compounds $(\mathbf{7 a}+\mathbf{7 b})$ which could not be separated by recrystallization is also sensitive to moisture and the analytical data for the isolated solid is consistent with an empirical formula $\mathbf{8} \cdot \mathrm{TiCl}_{4} \cdot$ toluene. 


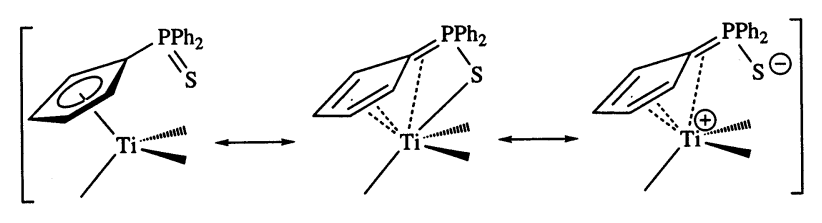

Fig. 3. Resonance structures proposed for a $\left[\mathrm{Ti}\left(\mathrm{C}_{5} \mathrm{H}_{4} \mathrm{P}(\mathrm{S}) \mathrm{Ph}_{2}\right)\right]$ moiety.

The ${ }^{1} \mathrm{H}$ - and ${ }^{31} \mathrm{P}-\mathrm{NMR}$ spectra of the yellow mixture 7 contain a set of signals corresponding to ligands; the ratio of the $\mathrm{C}_{5} \mathrm{H}_{4} \mathrm{P}(\mathrm{S}) \mathrm{Ph}_{2}$ ligands for the two components $\mathbf{7 a} / \mathbf{7 b}$ is around $1: 1$, although it varies slightly depending on the sample. We propose $\mathbf{7 a}$ and $\mathbf{7 b}$ to be two compounds with structures containing $\mathrm{TiCl}_{4}$ bridges formed by coordination of the sulfur atoms from two $\mathrm{C}_{5} \mathrm{H}_{4} \mathrm{P}(\mathrm{S}) \mathrm{Ph}_{2}$ ligands to titanium (Fig. 3) [17].

Compounds $7 \mathbf{a}$ and $\mathbf{7 b}$ are formed from the reaction of the bis(cyclopentadienyl) complex $\mathbf{8}$, or from the mono(cyclopentadienyl) $\mathbf{6}$, with 1 equiv. of $\mathrm{TiCl}_{4}$. Moreover, the observations described above are consistent with an equilibrium between $\mathbf{6}$ and $\mathbf{7}$ in solution, where 7 precipitates due to its lower solubility in toluene. This equilibrium can be explained if the ring substituent leads to a weaker titanium-cyclopentadienyl bond. The lower covalency would reduce the directional constraints of the bond, thus allowing intermolecular ligand redistribution between 6 and 7. There must also be a solvent effect in this equilibrium, since $\mathbf{6}$ is quantitatively converted into 7 , reducing the toluene content of the sample.

\section{Conclusions}

The cyclopentadiene $\mathrm{C}_{5} \mathrm{H}_{4}\left(\mathrm{SiMe}_{3}\right) \mathrm{PPh}_{2}$ (1) reacts with $\mathrm{TiCl}_{4}$ to yield the trichlorotitanium complex $\mathbf{2}$ which can be alkylated to give the tribenzyl derivative 5. The crystal structure of $\mathbf{4}$ confirmed the $\eta^{5}$-coordination of the substituted cyclopentadienyl ring. The $\mathrm{C}_{5} \mathrm{H}_{4} \mathrm{P}(\mathrm{S}) \mathrm{Ph}_{2}$ ligand give rise to mono- and bis(cyclopentadienyl)titanium complexes 6-9. The common structural feature in these titanium complexes is the $\eta^{5}$-coordination of the substituted cyclopentadienyl ring to the metal center. However, their chemical behavior indicate that the cyclopentadienyl-titanium bond is weaker as a result of ionic bonding contribution caused by the presence of the phosphorus substituent on the ring.

\section{Experimental}

\subsection{General methods}

All operations were performed under argon with Schlenk or dry-box techniques. All common chemicals and solvents were purchased from commercial suppliers and purified as described elsewhere [18]. (Trimethylsilyl)cyclopentadiene [19], (diphenylthiophosphoryl)cyclopentadiene [16], $\left(\mathrm{C}_{6} \mathrm{H}_{5} \mathrm{CH}_{2}\right)_{2} \mathrm{Mg}(\mathrm{THF})_{2}$ [20] and $\operatorname{Ti}\left(\eta^{5}-\mathrm{C}_{5} \mathrm{H}_{5}\right) \mathrm{Cl}_{3}$ [9a], were prepared according to literature procedures. NMR spectra were recorded at $25^{\circ} \mathrm{C}$ on Varian Unity $500+$, Varian Unity VXR-300 or Varian Unity 200 NMR spectrometers. Chemical shifts $(\delta)$ are reported in ppm referenced to tetramethylsilane for ${ }^{1} \mathrm{H}$ and ${ }^{13} \mathrm{C}$, and to $\mathrm{H}_{3} \mathrm{PO}_{4}$ for ${ }^{31} \mathrm{P}$. Elemental analyses were performed by the University of Alcalá Microanalytical Laboratories (UCSA) on a Heraeus CHN-O-Rapid- and by the University of Mainz Analytical Laboratory on a Heraeus CHN-Vario EL microanalyzer. Mass spectra were recorded on HewlettPackard 5890 and Finnigan 8230 mass spectrometers.

\subsection{Preparation of $\mathrm{C}_{5} \mathrm{H}_{4}\left(\mathrm{SiMe}_{3}\right)\left(\mathrm{PPh}_{2}\right)$ (1)}

A solution of $\mathrm{Ph}_{2} \mathrm{PCl}(5.9 \mathrm{ml}, 32.8 \mathrm{mmol})$ in hexane $(20 \mathrm{ml})$ was added dropwise, at $0^{\circ} \mathrm{C}$, to a suspension of $\mathrm{Li}\left(\mathrm{C}_{5} \mathrm{H}_{4} \mathrm{SiMe}_{3}\right)(94.73 \mathrm{~g}, 32.8 \mathrm{mmol})$ in hexane $(130 \mathrm{ml})$. The reaction mixture was slowly warmed to room temperature and stirred overnight. After filtration of lithium chloride and washing the filterbed with hexane $(20 \mathrm{ml})$, the filtrate was evaporated, giving $\mathbf{1}$ as an orange-yellow oil. Yield: $9.98 \mathrm{~g}(94 \%) .{ }^{1} \mathrm{H}-\mathrm{NMR}$ (200 $\left.\mathrm{MHz}, \mathrm{CDCl}_{3}\right): \delta=-0.04\left(\mathrm{~s}, 9 \mathrm{H}, \mathrm{SiCH}_{3}\right), 3.07(\mathrm{~m}$, $\left.0.5 \mathrm{H}, \mathrm{C}_{5} \mathrm{H}_{4}\right), 3.47\left(\mathrm{~s}, 0.5 \mathrm{H}, \mathrm{C}_{5} \mathrm{H}_{4}\right), 6.50\left(\mathrm{~m}, 3 \mathrm{H}, \mathrm{C}_{5} \mathrm{H}_{4}\right)$, $7.20\left(\mathrm{~m}, 10 \mathrm{H}, \mathrm{C}_{6} \mathrm{H}_{5}\right) ; \mathrm{MS}(70 \mathrm{eV}, \mathrm{EI}): m / z(\%)=322$ (24) $\left[\mathrm{M}^{+}\right], 250(29)\left[\mathrm{M}^{+}-\mathrm{SiMe}_{3}\right], 183$ (28) $\left[\mathrm{PPh}_{2}^{+}\right], 73$ (100) $\left[\mathrm{SiMe}_{3}^{+}\right]$.

\subsection{Preparation of $\left.\mathrm{Li}_{\{} \mathrm{C}_{5} \mathrm{H}_{4} \mathrm{P}(\mathrm{S}) \mathrm{Ph}_{2}\right\}(\mathrm{THF})_{2}$ (2)}

A solution of $n$-butyllithium $(4.4 \mathrm{ml}, 1.6 \mathrm{M}$ in hexanes) was added dropwise to a THF solution $(150 \mathrm{ml})$ of $\mathrm{C}_{5} \mathrm{H}_{5} \mathrm{P}(\mathrm{S}) \mathrm{Ph}_{2}(2.00 \mathrm{~g}, 7.08 \mathrm{mmol})$ at $-78^{\circ} \mathrm{C}$. The reaction mixture was allowed to warm to room temperature and stirred for an additional $3 \mathrm{~h}$. The solvent was removed under vacuum, and the resulting yellow oil treated with cold hexane $(2 \times 30 \mathrm{ml})$ to give $\mathbf{2}$ as a foamy yellowish-white solid in quantitative yield. This air-sensitive lithium salt was isolated as an adduct with 2 equiv. of THF as indicated by ${ }^{1} \mathrm{H}-\mathrm{NMR} .{ }^{1} \mathrm{H}-\mathrm{NMR}$ $\left(200 \mathrm{MHz}, \mathrm{C}_{6} \mathrm{D}_{6}\right): \delta=1.24$ (m, 8H, THF), $3.38(\mathrm{~m}, 8 \mathrm{H}$, THF), $6.45\left(\mathrm{bd}, 4 \mathrm{H},{ }^{1} J(\mathrm{P}, \mathrm{H})=4.5 \mathrm{~Hz}, \mathrm{C}_{5} \mathrm{H}_{4}\right), 7.00-$ $7.10\left(\mathrm{~m}, 6 \mathrm{H}, \mathrm{C}_{6} \mathrm{H}_{5}\right.$-meta and para $), 8.20-8.33(\mathrm{dm}, 4 \mathrm{H}$, ${ }^{3} J(\mathrm{P}, \mathrm{H})=13.2 \mathrm{~Hz}, \mathrm{C}_{6} \mathrm{H}_{5}$-ortho $) ;{ }^{31} \mathrm{P}\left\{{ }^{1} \mathrm{H}\right\}-\mathrm{NMR}(121$ $\mathrm{MHz}, \mathrm{C}_{6} \mathrm{D}_{6}$ ): $\delta=41.18$ (s).

\subsection{Preparation of $\mathrm{Tl}\left\{\left(\mathrm{C}_{5} \mathrm{H}_{4}\right) \mathrm{P}(\mathrm{S}) \mathrm{Ph}_{2}\right\}$ (3)}

A reaction of TlOEt $(0.8 \mathrm{ml}, 11.33 \mathrm{mmol})$ with $\mathrm{C}_{5} \mathrm{H}_{5} \mathrm{P}(\mathrm{S}) \mathrm{Ph}_{2}(3.20 \mathrm{~g}, 11.33 \mathrm{mmol})$ was carried out in 
diethyl ether $(200 \mathrm{ml})$ at $0^{\circ} \mathrm{C}$. The resulting brown suspension was stirred for $2 \mathrm{~h}$ at room temperature. Then, the solvent was separated by filtration and the solid washed with hexane $(2 \times 30 \mathrm{ml})$ affording compound 3 as an air-sensitive brown solid. Yield: $5.02 \mathrm{~g}$ $(92 \%)$. ${ }^{1} \mathrm{H}-\mathrm{NMR}\left(300 \mathrm{MHz}, \mathrm{C}_{6} \mathrm{D}_{6}\right): \delta=6.17(\mathrm{dt}, 2 \mathrm{H}$, $\left.J(\mathrm{P}, \mathrm{H})=4.0 \mathrm{~Hz}, \mathrm{C}_{5} \mathrm{H}_{4}\right), 6.48(\mathrm{dt}, 2 \mathrm{H}, J(\mathrm{P}, \mathrm{H})=4.0 \mathrm{~Hz}$, $\left.\mathrm{C}_{5} \mathrm{H}_{4}\right), 7.01-7.07\left(\mathrm{~m}, 6 \mathrm{H}, \mathrm{C}_{6} \mathrm{H}_{5}\right.$-meta and para), 8.18$8.24\left(\mathrm{dm}, \quad 4 \mathrm{H}, \quad{ }^{3} \mathrm{~J}(\mathrm{P}, \mathrm{H})=15.0 \quad \mathrm{~Hz}, \quad \mathrm{C}_{6} \mathrm{H}_{5}\right.$-ortho $)$; ${ }^{13} \mathrm{C}\left\{{ }^{1} \mathrm{H}\right\}-\mathrm{NMR} \quad\left(75 \mathrm{MHz}, \quad \mathrm{C}_{6} \mathrm{D}_{6}\right): \quad \delta=111.63 \quad(\mathrm{~d}$, $\left.J(\mathrm{P}, \mathrm{C})=15.2 \mathrm{~Hz}, \mathrm{C}_{5} \mathrm{H}_{4}\right), 115.02\left(\mathrm{~d},{ }^{1} J(\mathrm{P}, \mathrm{C})=102.5\right.$ $\mathrm{Hz}, \mathrm{C}_{5} \mathrm{H}_{4}$-ipso $), 115.69\left(\mathrm{~d}, J(\mathrm{P}, \mathrm{C})=14.0 \mathrm{~Hz}, \mathrm{C}_{5} \mathrm{H}_{4}\right)$, $128.19\left(\mathrm{~d},{ }^{3} J(\mathrm{P}, \mathrm{C})=26.3 \mathrm{~Hz}, \mathrm{C}_{6} \mathrm{H}_{5}-\right.$ meta $), 131.98(\mathrm{~d}$, ${ }^{4} J(\mathrm{P}, \mathrm{C})=3.1 \mathrm{~Hz}, \mathrm{C}_{6} \mathrm{H}_{5}$-para $), 132.64\left(\mathrm{~d},{ }^{2} J(\mathrm{P}, \mathrm{C})=11.0\right.$ $\mathrm{Hz}, \mathrm{C}_{6} \mathrm{H}_{5}$-ortho $), 132.65\left(\mathrm{~d},{ }^{1} J(\mathrm{P}, \mathrm{C})=83.6 \mathrm{~Hz}, \mathrm{C}_{6} \mathrm{H}_{5^{-}}\right.$ ipso); ${ }^{31} \mathrm{P}\left\{{ }^{1} \mathrm{H}\right\}$-NMR (121 MHz, $\left.\mathrm{C}_{6} \mathrm{D}_{6}\right): \delta=38.75$ (s). Anal. Calc. for $\mathrm{C}_{17} \mathrm{H}_{14}$ PSTl: C 42.04, H 2.90. Found: C 41.48, H 2.89 .

\subsection{Preparation of $\mathrm{Ti}\left(\eta^{5}-\mathrm{C}_{5} \mathrm{H}_{4} \mathrm{PPh}_{2}\right) \mathrm{Cl}_{3}$ (4)}

A solution of $1(1.97 \mathrm{~g}, 6.12 \mathrm{mmol})$ in $15 \mathrm{ml}$ of $\mathrm{CH}_{2} \mathrm{Cl}_{2}$ was added dropwise, at $-78^{\circ} \mathrm{C}$, to a solution of $\mathrm{TiCl}_{4}(0.58 \mathrm{ml}, 5.27 \mathrm{mmol})$ in $140 \mathrm{ml}$ of $\mathrm{CH}_{2} \mathrm{Cl}_{2}$. The solution immediately turned to a purple color. It was warmed slowly to room temperature and stirred overnight. After evaporation of the solvent, the crude product was obtained as a purple microcrystalline solid, which was recrystallized from hexane $/ \mathrm{CH}_{2} \mathrm{Cl}_{2}$ to give purple single crystals. Yield: $2.12 \mathrm{~g}(86 \%) .{ }^{1} \mathrm{H}-\mathrm{NMR}$ $\left(200 \mathrm{MHz}, \mathrm{CDCl}_{3}\right): \delta=6.88\left(\mathrm{~m}, 2 \mathrm{H}, \mathrm{C}_{5} \mathrm{H}_{4}\right), 7.01(\mathrm{~m}, 2$ $\left.\mathrm{H}, \mathrm{C}_{5} \mathrm{H}_{4}\right), 7.38\left(\mathrm{~d}, 10 \mathrm{H}, \mathrm{C}_{6} \mathrm{H}_{5}\right) ;{ }^{13} \mathrm{C}\left\{{ }^{1} \mathrm{H}\right\}-\mathrm{NMR}(125$ $\left.\mathrm{MHz}, \mathrm{CDCl}_{3}\right): \delta=125.1\left(\mathrm{~s}, \mathrm{C}_{5} \mathrm{H}_{4}\right), 126.4\left(\mathrm{~d},{ }^{4} J(\mathrm{P}, \mathrm{C})=\right.$ $8.25 \mathrm{~Hz}, \mathrm{C}_{6} \mathrm{H}_{5}$-para $), 128.9\left(\mathrm{~d},{ }^{3} J(\mathrm{P}, \mathrm{C})=7.75 \mathrm{~Hz}\right.$, $\mathrm{C}_{6} \mathrm{H}_{5}$-meta), $129.9\left(\mathrm{~s}, \mathrm{C}_{5} \mathrm{H}_{4}\right), 134.1\left(\mathrm{~d},{ }^{2} J(\mathrm{P}, \mathrm{C})=23.88\right.$ $\mathrm{Hz}, \mathrm{C}_{6} \mathrm{H}_{5}$-ortho $), 134.80\left(\mathrm{~d},{ }^{1} J(\mathrm{P}, \mathrm{C})=11.88 \mathrm{~Hz}, \mathrm{C}_{6} \mathrm{H}_{5^{-}}\right.$ ipso $), \quad 142.5\left(\mathrm{~d}, \quad{ }^{1} J(\mathrm{P}, \mathrm{C})=25.38 \quad \mathrm{~Hz}, \quad \mathrm{C}_{5} \mathrm{H}_{4}-i p s o\right)$; ${ }^{31} \mathrm{P}\left\{{ }^{1} \mathrm{H}\right\}-\mathrm{NMR}\left(121 \mathrm{MHz}, \mathrm{C}_{6} \mathrm{D}_{6}\right): \delta=6.64$ (s). Anal. Calc. for $\mathrm{C}_{17} \mathrm{H}_{14} \mathrm{Cl}_{3} \mathrm{PTi}$ : C 50.75, $\mathrm{H}$ 3.51. Found: $\mathrm{C}$ 52.07, H, 3.83.

\subsection{Preparation of $\mathrm{Ti}\left(\mathrm{C}_{5} \mathrm{H}_{4} \mathrm{PPh}_{2}\right)\left(\mathrm{CH}_{2} \mathrm{C}_{6} \mathrm{H}_{5}\right)_{3}$}

A filtered solution of 4 (428 mg, $1.06 \mathrm{mmol})$ in $20 \mathrm{ml}$ of toluene was added to a suspension of $\left(\mathrm{C}_{6} \mathrm{H}_{5} \mathrm{CH}_{2}\right)_{2} \mathrm{Mg}(\mathrm{THF})_{2}(677 \mathrm{mg}, 1.93 \mathrm{mmol})$ in $20 \mathrm{ml}$ of hexane at $-78^{\circ} \mathrm{C}$. After allowing to warm up to room temperature, the reaction mixture was stirred for $20 \mathrm{~h}$. Filtration and evaporation of the solvent gave a red oily residue which was dissolved in hexane and stored at $-35^{\circ} \mathrm{C}$ to afford brown microcrystals. Yield: $0.22 \mathrm{~g}$ (20\%). ${ }^{1} \mathrm{H}-\mathrm{NMR}\left(400 \mathrm{MHz}, \mathrm{C}_{6} \mathrm{D}_{6}\right): \delta=3.00(\mathrm{~s}, 6 \mathrm{H}$, $\left.\mathrm{TiCH}_{2}\right), 5.64\left(\mathrm{~m}, 2 \mathrm{H}, \mathrm{C}_{5} \mathrm{H}_{4}\right), 5.85\left(\mathrm{~m}, 2 \mathrm{H}, \mathrm{C}_{5} \mathrm{H}_{4}\right)$, 6.77-7.51 (m, 25 H, $\mathrm{PC}_{6} \mathrm{H}_{5}$ and $\left.\mathrm{CH}_{2} \mathrm{C}_{6} H_{5}\right) ;{ }^{13} \mathrm{C}\left\{{ }^{1} \mathrm{H}\right\}-$ NMR $\left(100 \mathrm{MHz}, \mathrm{C}_{6} \mathrm{D}_{6}\right): \delta=93.9\left(\mathrm{TiCH}_{2}\right), 120.1(\mathrm{~d}$, ${ }^{4} J(\mathrm{P}, \mathrm{C})=10.3 \mathrm{~Hz}, \quad \mathrm{PC}_{6} \mathrm{H}_{5}$-para $), 120.5 \quad\left(\mathrm{CH}_{2} \mathrm{C}_{6} \mathrm{H}_{5^{-}}\right.$ para), $123.2\left(\mathrm{CH}_{2} \mathrm{C}_{6} \mathrm{H}_{5}\right.$-meta $), 127.2,128.8\left(\mathrm{C}_{5} \mathrm{H}_{4}\right)$, $128.9 \quad\left(\mathrm{~d}, \quad{ }^{3} J(\mathrm{P}, \mathrm{C})=7.7 \quad \mathrm{~Hz}, \quad \mathrm{PC}_{6} \mathrm{H}_{5}\right.$-meta $), \quad 129.5$ $\left(\mathrm{CH}_{2} \mathrm{C}_{6} \mathrm{H}_{5}\right.$-ortho $), 134.2\left(\mathrm{~d},{ }^{1} J(\mathrm{P}, \mathrm{C})=20.5 \mathrm{~Hz}, \mathrm{C}_{5} \mathrm{H}_{4}-\right.$ ipso $), 134.7\left(\mathrm{~d},{ }^{2} J(\mathrm{P}, \mathrm{C})=21.1 \mathrm{~Hz}, \mathrm{PC}_{6} \mathrm{H}_{5}\right.$-ortho $), 137.9$ $\left(\mathrm{d},{ }^{1} J(\mathrm{P}, \mathrm{C})=11.0 \mathrm{~Hz}, \mathrm{PC}_{6} \mathrm{H}_{5}\right.$-ipso $), 148.6\left(\mathrm{CH}_{2} \mathrm{C}_{6} \mathrm{H}_{5}-\right.$ ipso); MS (70 eV, EI): $m / z(\%)=250$ (12) $\left[\mathrm{M}^{+}-\mathrm{PPh}_{2}\right.$, $\left.-2 \mathrm{C}_{7} \mathrm{H}_{7}\right], 186$ (11) $\left[\mathrm{C}_{5} \mathrm{H}_{4} \mathrm{TiCH}_{2}^{+}\right], 108$ (31) $\left[\mathrm{PC}_{6} \mathrm{H}_{6}^{+}\right]$. Anal. Calc. for $\mathrm{C}_{38} \mathrm{H}_{35}$ PTi: C 79.99, H 6.20. Found: C 76.93, H 5.82 .

\subsection{Preparation of $\mathrm{Ti}_{\{}\left\{\eta^{5}-\mathrm{C}_{5} \mathrm{H}_{4} \mathrm{P}(\mathrm{S}) \mathrm{Ph}_{2}\right\} \mathrm{Cl}_{3}$ (6)}

\subsubsection{Procedure $A$}

A suspension of the thallium salt $3(2.00 \mathrm{~g}, 4.12$ $\mathrm{mmol})$ in toluene $(100 \mathrm{ml})$ was slowly added in small portions, by cannula, to a solution of $\mathrm{TiCl}_{4}(0.45 \mathrm{ml}$, $4.12 \mathrm{mmol})$ in toluene $(50 \mathrm{ml})$ at $-40^{\circ} \mathrm{C}$. After stirring overnight at room temperature, the volatiles were evaporated and the residue was extracted into toluene (40 $\mathrm{ml})$ to give 6. Yield: $1.15 \mathrm{~g}$, (64\%).

\subsubsection{Procedure $B$}

A solution of the lithium salt $2(2.04 \mathrm{~g}, 7.08 \mathrm{mmol})$ in toluene $(50 \mathrm{ml})$ was added dropwise to another solution of $\mathrm{TiCl}_{4}$ in the same solvent $(50 \mathrm{ml})$ at $-40^{\circ} \mathrm{C}$. The yellow reaction mixture was allowed to warm gradually to room temperature, stirred for $20 \mathrm{~min}$, and the $\mathrm{LiCl}$ byproduct was filtered out. The solvent of the filtrate was then removed under reduced pressure, affording compound 6 (spectroscopic purity 95\%) mixed with a small amount of non separable $\mathrm{TiCl}_{4}(\mathrm{THF})_{2}$. Yield: $2.75 \mathrm{~g},(89 \%)$.

\subsubsection{Procedure $C$}

A solution of $\mathrm{TiCl}_{4}(0.07 \mathrm{ml}, 0.65 \mathrm{mmol})$ in toluene $(50 \mathrm{ml})$ was slowly added to a stirring solution of the bis(cyclopentadienyl) compound 8 (0.44 g, $0.65 \mathrm{mmol}$, vide infra) in toluene $(50 \mathrm{ml})$ at room temperature. After the addition was completed, the reaction mixture was kept at $60^{\circ} \mathrm{C}$ overnight, then cooled to room temperature and a yellow precipitate (mixtures of compounds 7 , vide infra) was filtered out, and the volatiles of the filtrate removed under vacuum to give compound 6. Yield: $0.05 \mathrm{~g}(18 \%)$.

Regardless of the procedure used, compound 6 was obtained as a very moisture-sensitive yellow-orange oil, and both ${ }^{1} \mathrm{H}-\mathrm{NMR}$ and elemental analyses indicate that it was isolated with 1 equiv. of remaining toluene. ${ }^{1} \mathrm{H}-\mathrm{NMR}\left(300 \mathrm{MHz}, \mathrm{C}_{6} \mathrm{D}_{6}\right): \delta=6.02\left(\mathrm{q}, 2 \mathrm{H}, \mathrm{C}_{5} \mathrm{H}_{4}\right)$, $6.79\left(\mathrm{q}, 2 \mathrm{H}, \mathrm{C}_{5} \mathrm{H}_{4}\right), 6.92-7.05\left(\mathrm{~m}, 6 \mathrm{H}, \mathrm{C}_{6} \mathrm{H}_{5}\right.$-meta and para), $7.58-7.66\left(\mathrm{dm}, 4 \mathrm{H},{ }^{3} \mathrm{~J}(\mathrm{P}, \mathrm{H})=13.9 \mathrm{~Hz}, \mathrm{C}_{6} \mathrm{H}_{5}\right.$-ortho ); ${ }^{31} \mathrm{P}\left\{{ }^{1} \mathrm{H}\right\}-\mathrm{NMR}\left(121 \mathrm{MHz}, \mathrm{C}_{6} \mathrm{D}_{6}\right): \delta=38.82$ (s). Anal. Calc. for $\mathrm{C}_{17} \mathrm{H}_{14} \mathrm{Cl}_{3} \mathrm{PSTi}^{-} \mathrm{C}_{7} \mathrm{H}_{8}$ : C 54.62, H 4.20 . Found: C 54.20, H 4.10. 


\subsection{Preparation of $\left[\mathrm{Ti}\left\{\left(\eta^{5}-\mathrm{C}_{5} \mathrm{H}_{4}\right) \mathrm{P}(\mathrm{S}) \mathrm{Ph}_{2}\right\}_{2} \mathrm{Cl}_{2} \cdot \mathrm{TiCl}_{4}\right]_{n}$ (7a and $7 b)$}

\subsubsection{Procedure $A$}

Following the reaction described in Procedure $\mathrm{C}$ to prepare compound $\mathbf{6}$, the mixture of compounds 7 was separated by filtration as the major product. Yield: 0.39 $\mathrm{g}(62 \%)$.

\subsubsection{Procedure $B$}

Samples of compound 6 were kept under high vacuum $\left(10^{-6}\right.$ mbar $)$, at room temperature overnight, converting the oily mono(cyclopentadienyl) compound into the mixture 7. Yield: quantitative.

In addition, attempts to crystallize compound $\mathbf{6}$ all failed (toluene, toluene $/ \mathrm{CH}_{2} \mathrm{Cl}_{2}$ or hexane/toluene), instead, they resulted in the separation of several crops of 7. The mixture 7 was obtained as a moisture-sensitive yellow microcrystalline solid. ${ }^{1} \mathrm{H}-\mathrm{NMR}$ and elemental analysis indicate the presence of toluene in the mixture, according to a general formula $\left[\mathrm{Ti}\left\{\left(\eta^{5}\right.\right.\right.$ $\left.\left.\mathrm{C}_{5} \mathrm{H}_{4}\right) \mathrm{P}(\mathrm{S}) \mathrm{Ph}_{2}\right\}_{2} \mathrm{Cl}_{2} \cdot\left(\mathrm{TiCl}_{4}\right) \cdot$ toluene $]_{n}$ This composition was unchanged when the solid was kept under high vacuum $\left(10^{-6} \mathrm{mbar}\right)$ overnight at $50^{\circ} \mathrm{C}$. ${ }^{1} \mathrm{H}-\mathrm{NMR}(300$ $\left.\mathrm{MHz}, \mathrm{C}_{6} \mathrm{D}_{6}\right): \delta=6.19\left(\mathrm{q}, 2 \mathrm{H}, \mathrm{C}_{5} \mathrm{H}_{4}-7 \mathrm{a}\right), 6.24(\mathrm{q}, 2 \mathrm{H}$, $\left.\mathrm{C}_{5} \mathrm{H}_{4}-7 \mathbf{a}\right), 6.55\left(\mathrm{q}, 2 \mathrm{H}, \quad \mathrm{C}_{5} \mathrm{H}_{4}-7 \mathbf{b}\right), 6.94(\mathrm{q}, 2 \mathrm{H}$, $\left.\mathrm{C}_{5} \mathrm{H}_{4}-7 \mathrm{~b}\right), 6.96-7.04\left(\mathrm{~m}, 6 \mathrm{H}+6 \mathrm{H}, \mathrm{C}_{6} \mathrm{H}_{5}\right.$-meta and para-7a and $7 \mathbf{b}), 7.37-7.46\left(\mathrm{dm}, 4 \mathrm{H},{ }^{3} J(\mathrm{P}, \mathrm{H})=13.5\right.$ $\mathrm{Hz}, \mathrm{C}_{6} \mathrm{H}_{5}$-ortho-7a), 7.66-7.74 (m, 4H, $\mathrm{C}_{6} \mathrm{H}_{5}$-ortho-7b); ${ }^{31} \mathrm{P}\left\{{ }_{1}^{1} \mathrm{H}\right\}$-NMR (121 MHz, $\left.\mathrm{C}_{6} \mathrm{D}_{6}\right): \delta=39.06$ (s, 7a), 39.16 (s, 7b). Anal. Calc. for $\mathrm{C}_{34} \mathrm{H}_{28} \mathrm{Cl}_{6} \mathrm{P}_{2} \mathrm{~S}_{2} \mathrm{Ti}_{2} \cdot \mathrm{C}_{7} \mathrm{H}_{8}$ : C 50.86, H 3.91. Found: C 51.12, H 3.77.

\subsection{Preparation of $\mathrm{Ti}\left\{\eta^{5}-\mathrm{C}_{5} \mathrm{H}_{4} \mathrm{P}(\mathrm{S}) \mathrm{Ph}_{2}\right\}_{2} \mathrm{Cl}_{2}(\boldsymbol{8})$}

A suspension of the precursor $3(2.50 \mathrm{~g}, 5.15 \mathrm{mmol})$ in toluene $(100 \mathrm{ml})$ was slowly added in small portions to a solution of $\mathrm{TiCl}_{4}(0.45 \mathrm{ml}, 4.12 \mathrm{mmol})$ in toluene $(50 \mathrm{ml})$ at $-78{ }^{\circ} \mathrm{C}$. After the addition, the red solution was allowed to warm to room temperature, followed by stirring for $2 \mathrm{~h}$ and filtration of the $\mathrm{TlCl}$ byproduct. Concentration of the toluene solution and cooling overnight afforded $\mathbf{8}$ as a moisture-sensitive red microcrystalline solid, which was recrystallized from toluene. Yield: $0.63 \mathrm{~g}(36 \%) .{ }^{1} \mathrm{H}-\mathrm{NMR}\left(300 \mathrm{MHz}, \mathrm{C}_{6} \mathrm{D}_{6}\right): \delta=$ $6.67\left(\mathrm{q}, 4 \mathrm{H} \mathrm{C}_{5} \mathrm{H}_{4}\right), 7.42$ (q, 4H $\left.\mathrm{C}_{5} \mathrm{H}_{4}\right), 6.94-7.02(\mathrm{~m}$, $12 \mathrm{H} \quad \mathrm{C}_{6} \mathrm{H}_{5}$-meta and para), 7.56-7.66 (dm, 8H ${ }^{3} J(\mathrm{P}, \mathrm{H})=13.6 \mathrm{~Hz}, \mathrm{C}_{6} \mathrm{H}_{5}$-ortho $) ;{ }^{13} \mathrm{C}\left\{{ }^{1} \mathrm{H}\right\}$-NMR $(125$ $\left.\mathrm{MHz}, \mathrm{C}_{6} \mathrm{D}_{6}\right): \delta=118.64\left(\mathrm{~d},{ }^{1} J(\mathrm{P}, \mathrm{C})=87.5 \mathrm{~Hz}, \mathrm{C}_{5} \mathrm{H}_{4}-\right.$ ipso $), 125.68\left(\mathrm{~d}, J(\mathrm{P}, \mathrm{C})=10.9 \mathrm{~Hz}, \mathrm{C}_{5} \mathrm{H}_{4}\right), 129.02(\mathrm{~d}$, $\left.J(\mathrm{P}, \mathrm{C})=10.2 \mathrm{~Hz}, \mathrm{C}_{5} \mathrm{H}_{4}\right), 128.58\left(\mathrm{~d},{ }^{3} J(\mathrm{P}, \mathrm{C})=13.3 \mathrm{~Hz}\right.$, $\mathrm{C}_{6} \mathrm{H}_{5}$-meta), $131.68\left(\mathrm{~d}, J(\mathrm{P}, \mathrm{C})=3.1 \mathrm{~Hz}, \mathrm{C}_{6} \mathrm{H}_{5}\right.$-para $)$, $132.20\left(\mathrm{~d},{ }^{2} J(\mathrm{P}, \mathrm{C})=10.9 \mathrm{~Hz}, \mathrm{C}_{6} \mathrm{H}_{5}\right.$-ortho $), 133.91(\mathrm{~d}$, ${ }^{1} J(\mathrm{P}, \mathrm{C})=88.3 \mathrm{~Hz}, \mathrm{C}_{6} \mathrm{H}_{5}$-ipso $) ;{ }^{31} \mathrm{P}\left\{{ }^{1} \mathrm{H}\right\}-\mathrm{NMR} \quad(121$ $\left.\mathrm{MHz}, \quad \mathrm{C}_{6} \mathrm{D}_{6}\right): \quad \delta=40.59$ (s). Anal. Calc. for
$\mathrm{C}_{34} \mathrm{H}_{28} \mathrm{Cl}_{2} \mathrm{P}_{2} \mathrm{~S}_{2}$ Ti: C 59.93, H 4.14. Found: C 59.57, H 4.16 .

Crude 8 (spectroscopic purity $90-97 \%$ ) mixed with a small amount of inseparable $\mathrm{TiCl}_{4}(\mathrm{THF})_{2}$, was obtained from the dropwise addition of a solution of $\mathbf{2}$ in toluene to $1 / 2$ equiv. of $\mathrm{TiCl}_{4}$ in toluene at $-78^{\circ} \mathrm{C}$, and work-up of the reaction mixture. Yield: $40-45 \%$.

\subsection{Preparation of $\mathrm{Ti}\left\{\eta^{5}-\mathrm{C}_{5} \mathrm{H}_{4} P(S) P h_{2}\right\}\left(\eta^{5}-\mathrm{C}_{5} \mathrm{H}_{5}\right) \mathrm{Cl}_{2}$ (9)}

A mixture of $\mathrm{Ti}\left(\eta^{5}-\mathrm{C}_{5} \mathrm{H}_{5}\right) \mathrm{Cl}_{3}(0.58 \mathrm{~g}, 2.65 \mathrm{mmol})$ and $3(1.30 \mathrm{~g}, 2.65 \mathrm{mmol})$ was warmed up to $60^{\circ} \mathrm{C}$ in toluene $(100 \mathrm{ml})$ and stirred overnight. After filtration of the precipitate $(\mathrm{TlCl})$, the red solution was concentrated and cooled at $-30^{\circ} \mathrm{C}$ for $24 \mathrm{~h}$ to give compound 9 as a moisture-sensitive red microcrystalline solid. This product was recrystallized from $\mathrm{CH}_{2} \mathrm{Cl}_{2}$. Yield: $0.68 \mathrm{~g}$ $(55 \%)$. ${ }^{1} \mathrm{H}-\mathrm{NMR}\left(300 \mathrm{MHz}, \mathrm{C}_{6} \mathrm{D}_{6}\right): \delta=6.22(\mathrm{q}, 2 \mathrm{H}$ $\left.\mathrm{C}_{5} \mathrm{H}_{4}\right), 6.71$ (q, $\left.2 \mathrm{H} \mathrm{C}_{5} \mathrm{H}_{4}\right), 6.43\left(\mathrm{~s}, 5 \mathrm{H} \mathrm{C}_{5} \mathrm{H}_{5}\right), 6.96-7.02$ $\left(\mathrm{m}, 6 \mathrm{H} \quad \mathrm{C}_{6} \mathrm{H}_{5}-\right.$ meta and para), 7.54-7.63 (dm, 8H ${ }^{3} J(\mathrm{P}, \mathrm{H})=13.6 \mathrm{~Hz}, \mathrm{C}_{6} \mathrm{H}_{5}$-ortho $) ;{ }^{13} \mathrm{C}\left\{{ }^{1} \mathrm{H}\right\}-\mathrm{NMR} \quad(75$ $\left.\mathrm{MHz}, \mathrm{C}_{6} \mathrm{D}_{6}\right): \delta=115.13\left(\mathrm{~d},{ }^{1} J(\mathrm{P}, \mathrm{C})=86.3 \mathrm{~Hz}, \mathrm{C}_{5} \mathrm{H}_{4}-\right.$ ipso), $122.27\left(\mathrm{~s}, \mathrm{C}_{5} \mathrm{H}_{5}\right), 123.28(\mathrm{~d}, J(\mathrm{P}, \mathrm{C})=10.1 \mathrm{~Hz}$, $\left.\mathrm{C}_{5} \mathrm{H}_{4}\right), 126.85\left(\mathrm{~d}, J(\mathrm{P}, \mathrm{C})=10.1 \mathrm{~Hz}, \mathrm{C}_{5} \mathrm{H}_{4}\right), 128.51(\mathrm{~d}$, ${ }^{3} J(\mathrm{P}, \mathrm{C})=12.8 \mathrm{~Hz}, \mathrm{C}_{6} \mathrm{H}_{5}$-meta $), 131.72\left(\mathrm{bs}, \mathrm{C}_{6} \mathrm{H}_{5}\right.$-para $)$, $132.20\left(\mathrm{~d},{ }^{2} J(\mathrm{P}, \mathrm{C})=11.9 \mathrm{~Hz}, \mathrm{C}_{6} \mathrm{H}_{5}\right.$-ortho $), 133.97(\mathrm{~d}$, ${ }^{1} J(\mathrm{P}, \mathrm{C})=87.9 \mathrm{~Hz}, \quad \mathrm{C}_{6} \mathrm{H}_{5}$-ipso $) ;{ }^{31} \mathrm{P}\left\{{ }^{1} \mathrm{H}\right\}-\mathrm{NMR} \quad(121$

Table 2

Crystal data and structure refinement for complex $\mathrm{Ti}\left(\eta^{5}\right.$ $\left.\mathrm{C}_{5} \mathrm{H}_{4} \mathrm{PPh}_{2}\right) \mathrm{Cl}_{3}$ (4).

\begin{tabular}{ll}
\hline Formula & $\mathrm{C}_{17} \mathrm{H}_{14} \mathrm{Cl}_{3} \mathrm{PTi}$ \\
Formula weight $\left(\mathrm{g} \mathrm{mol}^{-1}\right)$ & 403.50 \\
Crystal color & Purple \\
Crystal size $(\mathrm{mm})$ & $0.63 \times 0.45 \times 0.38$ \\
Crystal system & Monoclinic \\
Space group & $P 2_{1} / c$ (no. 14) \\
Unit cell dimensions & \\
a $(\AA)$ & $10.629(4)$ \\
$b(\AA)$ & $6.484(2)$ \\
$c(\AA)$ & $25.169(8)$ \\
$\beta\left({ }^{\circ}\right)$ & $92.45(3)$ \\
$Z$ & 4 \\
$\rho_{\text {calc. }}\left(\mathrm{g}\right.$ cm $\left.{ }^{-3}\right)$ & 1.547 \\
$\left.\mu(\text { Mo-K })_{\alpha}\right)\left(\mathrm{mm}^{-1}\right)$ & 1.04 \\
Empirical transmission factors & $90.25-99.99 \%$ \\
$F(000)$ & 816 \\
$\theta$ scan range $\left({ }^{\circ}\right)$ & 30 \\
$T(\mathrm{~K})$ & $296(2)$ \\
Refl. measured & 8853 \\
Indep. refl. obs. $[I>2 \sigma(I)]$ & 5042 \\
Final $R$ indices $[\mathrm{I}>2 \sigma(\mathrm{I})]$ & $R_{1}=0.0289$, \\
& $w R_{2}=0.0718$ \\
Final $R$ indices $($ all data) & $R_{1}=0.0437$, \\
& $w R_{2}=0.0833$ \\
Goodness-of-fit & 1.098 \\
Parameters refined & 256 \\
Residual density: max., min. $\left(\mathrm{e} \AA^{-3}\right)$ & $0.358,-0.472$ \\
\end{tabular}


$\left.\mathrm{MHz}, \quad \mathrm{C}_{6} \mathrm{D}_{6}\right): \delta=41.06$ (s). Anal. Calc. for $\mathrm{C}_{22} \mathrm{H}_{19} \mathrm{Cl}_{2}$ PSTi: C 56.79, $\mathrm{H}$ 4.12. Found: C 57.16, H 4.13 .

\subsection{X-ray crystal structure analysis of $\mathbf{4}$}

Crystallographic data are summarized in Table 2. Single crystals of 4 were grown from a $\mathrm{CH}_{2} \mathrm{Cl}_{2} /$ hexane solution at $-35^{\circ} \mathrm{C}$. Data sets were obtained at $296 \mathrm{~K}$ using an ENRAF-Nonius CAD4 diffractometer $(\omega-$ scan mode, monochromatic $\mathrm{Mo}-\mathrm{K}_{\alpha}$ radiation, $\lambda=$ $0.7107 \AA$ ). The reflections were corrected for Lp effects using the program MOLEN [21a] and for absorption using $\psi$-scans. The structure was solved by direct and Fourier difference methods using the program SHELXs86 [21b]. The refinement was carried out with the program SHELXL93 based on $\mathrm{F}^{2}$ [21c]. Anisotropic thermal parameters were refined for all non-hydrogen atoms. All hydrogen atoms were located and refined in their positions with isotropic thermal parameters.

\section{Supplementary information}

Further details of the crystal structure determination are available on request from the Cambridge Crystallographic Data Centre as supplementary publication no. CCDC-120982. Copies of the data can be obtained free of charge from the Director, CCDC, 12 Union Road, Cambridge CB2 1EZ, UK; fax: + 44-1223-336033 or e-mail: deposit@ccdc.cam.ac.uk or http://www.ccdc. cam.ac.uk.

\section{Acknowledgements}

We gratefully acknowledge financial support by DGICYT (ref. no. PB-97-0776), Iberdrola, and the Fonds der Chemischen Industrie.

\section{References}

[1] (a) W.P. Hart, M.D. Rausch, Adv. Organomet. Chem. 21 (1982) 1. (b) N.J. Coville, K.E. du Plooy, W. Pickl, Coord. Chem. Rev. 116 (1992) 1. (c) C. Janiak, H. Schumann, Adv. Organomet. Chem. 33 (1991) 291. (d) J. Okuda, Top. Curr. Chem. 160 (1991) 97. (e) R.L. Halterman, Chem. Rev. 92 (1992) 965. (f) P.C. Möhring, N.J. Coville, J. Organomet. Chem. 479 (1994) 1.

[2] (a) J. Okuda, Comments Inorg. Chem. 16 (1994) 185. (b) P. Jutzi, T. Redeker, Eur. J. Inorg. Chem. (1998) 663. (c) R.T. Kettenbach, H. Butenschön, New. J. Chem. 14 (1990) 599. (d) M.D. Fryzuk, S.S.H. Mao, M.J. Zaworotko, L.R. MacGillivray, J. Am. Chem. Soc. 115 (1993) 5336. (e) W.A. Herrmann, M.J.A. Morawietz, T.S. Priermeier, K.J. Mashima, J. Organomet. Chem. 486 (1995) 291. (f) R. Beckhaus, J. Oster, B. Ganter, U. Englert, Organometallics 16 (1997) 3902. (g) B.E. Bosch G. Erker, R. Fröhlich, O. Meyer, Organometallics 16 (1997) 5449. (h) M. Enders, R. Rudolph, H. Pritzkow, J. Organomet. Chem. 549 (1997) 251.

[3] (a) A.L. McKnight, R.M. Waymouth, Chem. Rev. 98 (1998) 2587. (b) J. Okuda, T. Eberle, in: A. Togni, R.L. Halterman (Eds.), Metallocenes, Wiley-VCH: Weinheim, 1998, p. 415. (c) P. J. Shapiro, E. Bunel, W.P. Schaefer, J.E. Bercaw, Organometallics 9 (1990) 867. (d) J. Okuda, Chem. Ber. 123 (1990) 1649. (e) A.K. Hughes, A. Meetsma, J.H. Teuben, Organometallics 12 (1993) 1936. (d) D.D. Devore, F.J. Timmers, D.L. Hasha, R.K. Rosen, T.J. Marks, P.A. Deck, C.L. Stern, Organometallics 14 (1995) 3132. (e) D.W. Carpenetti, L. Kloppenburg, J.T. Kupec, J.L. Petersen, Organometallics 15 (1996) 1572. (f) J.C. Flores, J.C.W. Chien, M.D. Rausch, Organometallics 13 (1994) 4140. (g) J.C. Flores, J.S. Wood, J.C.W. Chien, M.D. Rausch, Organometallics 15 (1996) 4944. (h) M.V. Galakhov, G. Heinz, P. Royo, J. Chem. Soc. Chem. Commun. (1998) 17.

[4] P. Jutzi, Chem. Rev. 86 (1986) 983.

[5] (a) X.D. He, A. Maisonnat, F. Dahan, R. Poilblanc, Organometallics 6 (1987) 678. (b) X.D. He, A. Maisonnat, F. Dahan, R. Poilblanc, Organometallics 8 (1989) 2618. (c) G.K. Anderson, M. Lin, Organometallics 7 (1988) 2285. (d) M.D. Rausch, B.H. Edwards, R.D. Rogers, J.L. Atwood, J. Am. Chem. Soc. 105 (1983) 3882. (e) S. Rigny, J.C. Leblanc, B. Nuber, C. Moise, J. Chem. Soc. Dalton Trans. (1997) 1187. (f) C.P. Casey, F. Nief, Organometallics 4 (1985) 1218. (g) W.R. Tikannen, Y. Fuyita, J.L. Petersen, Organometallics 5 (1986) 888. (h) J.C. Leblanc, C. Moise, A. Maisonnat, R. Poilblanc, C. Charrier, F. Mathey, J. Organomet. Chem. 231 (1982) C43. (i) A. W. Rudie, D.W. Lichtenberg, M.L. Katcher, A. Davison, Inorg. Chem. 17 (1978) 2859. (j) J.J. Bishop, A. Davison, Inorg. Chem. 10 (1971) 826. (k) J.J. Bishop, A. Davison, Inorg. Chem. 10 (1971) 832. (1) N.E. Shore, H. Hope, Inorg. Chem. 102 (1980) 4251. (m) E. Delgado, J. Forniés, E. Henández, E. Lalinde, N. Mansilla, M.T. Moreno, J. Organomet. Chem. 494 (1995) 261. (n) I. Ara, E. Delgado, J. Forniés, E. Henández, E. Lalinde, N. Mansilla, M.T. Moreno, J. Chem. Soc. Dalton Trans. (1996) 3201.

[6] E. Delgado, M.A. García, E. Hernández, N. Mansilla, L.A. Martínez-Cruz, J. Tornero, R. Torres, J. Organomet. Chem. 560 (1998) 27.

[7] $\mathrm{Tl}^{0}$ : black metallic residue, green in flame test; $\mathrm{TlMe}_{3}$ : detected by ${ }^{1} \mathrm{H}-\mathrm{NMR}$ as a broad resonance $\left(\delta 0.46, W_{1 / 2}=40 \mathrm{~Hz}\right)$.

[8] (a) P. Jutzi, W. Leffers, J. Chem. Soc. Chem. Commun. (1985) 1735. (b) H. Werner, H. Otto, H.J. Kraus, J. Organomet. Chem. 315 (1986) C57. (c) S. Harvey, C.L. Raston, B.W. Skelton, A.H. White, M.F. Lappert, G. Srivastava, J. Organomet. Chem. 328 (1987) C1. (d) I. Dorado, J.C. Flores, M. Galakhov, P. GómezSal, A. Martín, P. Royo, J. Organomet. Chem. 563 (1998) 7.

[9] (a) A.M. Cardoso, R.J.H. Clark, S.J. Moorhouse, J. Chem. Soc. Dalton Trans. (1980) 1156. (b) G. Hidalgo, M. Mena, F. Palacios, P. Royo, R. Serrano, J. Organomet. Chem. 340 (1988) 37.

[10] (a) R.D. Rogers, M.M. Benning, L.K. Kurihara, K.J. Moriarty, M.D. Rausch, J. Organomet. Chem. 105 (1985) 6188. (b) T. Cuenca, J.C. Flores, R. Gómez, P. Gómez-Sal, M. Parra-Hake, P. Royo, Inorg. Chem. 32 (1993) 3608. (c) C.H. Winter, X.-X. Zhou, D.A. Dobbs, M.J. Heeg, Organometallics 10 (1991) 210.

[11] (a) M. Bochmann, in: E. W. Abel, F.G.A. Stone, G. Wilkinson (Eds.), Comprehensive Organometallic Chemistry II, vol. 4, Elsevier, New York, 1995, p. 273. (b) R. Poli, Chem. Rev. 91 (1991) 509

[12] (a) L.M. Engelhardt, R.I. Papasergio, C.L. Raston, A.H. White Organometallics 3 (1984) 18. (b) K. Kirschbaum, D.M. Giolando, Acta Crystallogr. C47 (1991) 2216. (c) S.L. Hart, D.J. Duncalf, J.J. Hastings, A. McCamley, P.C. Taylor, J. Chem. Soc. Dalton Trans. (1996) 2843. (d) K.A. Rufanov, A.V. Churakov, N.B. Kazennova, G.P. Brusova, D.A. Lemenovskii, L.G. Kuz'mina, J. Organomet. Chem. 498 (1995) 37. (e) R. 
Duchateau, S.J. Lancaster, M. Thornton-Pett, M. Bochmann, Organometallics 16 (1997) 4995. (f) A.V. Churakov, L.G. Kuz'mina, Acta Crystallogr. C52 (1996) 3037.

[13] (a) H. Köpf, S. Grabowski, R. Voigtländer, J. Organomet. Chem. 216 (1981) 185. (b) H.P. Klein, U. Thewalt, K. Doppert, R. Sánchez-Delgado, J. Organomet. Chem. 236 (1982) 189. (c) R.D. Gorsich J. Am. Chem. Soc. 82 (1960) 4211. (d) L.M. Babcok, V.W. Day, W.G. Klemperer, J. Chem. Soc. Chem. Commun. (1987) 858. (e) T. Carofiglio, C. Floriani, A. Sganellotti, M. Rosi, A. Chiesi-Villa, C. Rizzloi, J. Chem. Soc. Dalton Trans. (1992) 1081.

[14] (a) S.A. Giddings, Inorg. Chem. 3 (1964) 684. (b) S.A. Giddings, Inorg. Chem. 6 (1967) 849.

[15] $\mathrm{C}_{5} \mathrm{H}_{5} \mathrm{P}(\mathrm{S}) \mathrm{Ph}_{2}$ has been previously described by Mathey et al. [16]. Here we report detailed spectroscopic data for the major isomer $(>80 \%)$ in benzene- $\mathrm{d}_{6}$ and for the monodeuterated species $\mathrm{C}_{5} \mathrm{H}_{4} \mathrm{DP}(\mathrm{S}) \mathrm{Ph}_{2} .\left\{{ }^{1} \mathrm{H}-{ }^{1} \mathrm{H}\right\}$ decoupling experiments and computer analysis of the spectrum at $500 \mathrm{MHz}$ (g-NMR $3.6 \mathrm{r} 2$ for Mac) allowed the following assignments and determination of the corresponding coupling constants: ${ }^{1} \mathrm{H}-\mathrm{NMR}(500 \mathrm{MHz}$, $\mathrm{C}_{6} \mathrm{D}_{6}$ ): $\delta=3.15$ (quintet, $2 \mathrm{H} J_{\mathrm{ab}}=1.5 \mathrm{~Hz}, J_{\mathrm{ac}}$ and $J_{\mathrm{ad}}=1.3 \mathrm{~Hz}$, $\left.J(\mathrm{P}, \mathrm{H})=1.5 \mathrm{~Hz}, \mathrm{C}_{5} \mathrm{H}_{5}-\mathrm{H}_{\mathrm{a}}\right), 6.10\left(\mathrm{~m}, 1 \mathrm{H} J_{\mathrm{ab}}=1.5 \mathrm{~Hz}, J_{\mathrm{bc}}=5.1\right.$ $\left.\mathrm{Hz}, J_{\mathrm{bd}}=2.0 \mathrm{~Hz}, J(\mathrm{P}, \mathrm{H})=1.8 \mathrm{~Hz}, \mathrm{C}_{5} \mathrm{H}_{5}-\mathrm{H}_{\mathrm{b}}\right), 6.27(\mathrm{~m}, 1 \mathrm{H}$ $J_{\mathrm{ac}}=1.3 \mathrm{~Hz}, J_{\mathrm{bc}}=5.1 \mathrm{~Hz}, J_{\mathrm{cd}}=1.1 \mathrm{~Hz}, J(\mathrm{P}, \mathrm{H})=3.5 \mathrm{~Hz}$, $\left.\mathrm{C}_{5} \mathrm{H}_{5}-\mathrm{H}_{\mathrm{c}}\right), 6.64\left(\mathrm{dm}, 1 \mathrm{H} J_{\mathrm{ad}}=1.3 \mathrm{~Hz}, J_{\mathrm{bd}}=2.0 \mathrm{~Hz}, J_{\mathrm{cd}}=1.1\right.$
$\left.\mathrm{Hz}, J(\mathrm{P}, \mathrm{H})=9.4 \mathrm{~Hz}, \mathrm{C}_{5} \mathrm{H}_{5}-\mathrm{H}_{\mathrm{d}}\right), 6.96-7.03\left(\mathrm{~m}, 6 \mathrm{H} \mathrm{C}_{6} \mathrm{H}_{5}\right.$-meta and para $), 7.79-7.88\left(\mathrm{dm}, 4 \mathrm{H}^{3} J(\mathrm{P}, \mathrm{H})=13.5 \mathrm{~Hz}, \mathrm{C}_{6} \mathrm{H}_{5}\right.$-ortho $)$; ${ }^{31} \mathrm{P}\left\{{ }^{1} \mathrm{H}\right\}$-NMR (121 MHz, $\left.\mathrm{C}_{6} \mathrm{D}_{6}\right): \delta=39.51$ (s, major isomer), 38.44 (s, minor). The ${ }^{1} \mathrm{H}-\mathrm{NMR}$ spectrum of the monodeuterated compound is similar to the one described for $\mathrm{C}_{5} \mathrm{H}_{5} \mathrm{P}(\mathrm{S}) \mathrm{Ph}_{2}$, and a remarkable feature is the slightly lower chemical shift for $\mathrm{H}_{\mathrm{a}}(\delta$ 3.13) which appears as a broader signal $\left(W_{1 / 2}=12 \mathrm{~Hz}\right)$.

[16] F. Mathey, J.-P. Lampin, Tetrahedron 31 (1975) 2685.

[17] Octahedral complexes of the type $\operatorname{TiCl}_{4}\left(\mathrm{~L}_{2}\right)\left(\mathrm{L}_{2}=\right.$ bidentate ligand or two monodentate ligands) are well known. See for example: C.A. McAuliffe, D.S. Barratt, in: G. Wilkinson, R.D. Gillard, J.A. McCleverty (Eds.), Comprehensive Coordination Chemistry, vol. 3, Pergamon Press, 1987, p. 338.

[18] D.P. Perrin, W.L.F Armarego, Purification of Laboratory Chemicals, third ed., Oxford, Pergamon Press, 1988.

[19] (a) A.J. Ashe, J. Am. Chem. Soc. 92 (1970) 1233. (b) E.W. Abel, M.O. Duster, J. Organomet. Chem. 33 (1971) 161.

[20] R.R. Schrock, J. Organomet. Chem. 122 (1976) 209.

[21] (a) C.K. Fair, MOLEN, An Interactive Structure Solution Procedure, Enraf-Nonius, Delft, 1990. (b) G.M. Sheldrick, SHELXs-86, Program for the Solution of Crystal Structures, University of Göttingen, Germany, 1986. (c) G.M. Sheldrick, SHELXL-93, Program for the Refinement of Crystal Structures, University of Göttingen, Germany, 1993. 